\title{
INFLUENCE OF ENZYME PREPARATIONS ON COLLOID RESISTANCE OF BEER
}

\author{
V. Kosheva, T. Misyura, N. Popova \\ National University of Food Technologies
}

\begin{tabular}{|c|c|}
\hline Key words: & ABSTRACT \\
\hline $\begin{array}{l}\text { Enzymes } \\
\text { Hydrolysis } \\
\text { Colloid firmness } \\
\text { Proteins } \\
\text { Fermentation }\end{array}$ & \multirow{3}{*}{$\begin{array}{l}\text { The article presents the results of the study of the influence } \\
\text { of enzyme preparations on the colloidal stability of beer, } \\
\text { provided that they are introduced in various concentrations, } \\
\text { at different stages of the process and to improve the } \\
\text { technology of production of beer resistant to colloidal clou- } \\
\text { ding by the use of enzyme preparations of proteolytic action. } \\
\text { The values of the parameters providing the optimal value for } \\
\text { the predicted stability of the finished product are deter- } \\
\text { mined, as well as the factors that will enable to accelerate } \\
\text { the technological cycle of production and to receive the } \\
\text { finished products with high indicators of colloidal stability. }\end{array}$} \\
\hline \begin{tabular}{l}
\multicolumn{1}{c}{ Article history: } \\
Received 15.05.2017 \\
Received in revised form \\
14.06 .2017 \\
Accepted 28.06 .2017
\end{tabular} & \\
\hline $\begin{array}{l}\text { Corresponding author: } \\
\text { V. Kosheva } \\
\text { E-mail: } \\
\text { npnuht@ukr.net }\end{array}$ & \\
\hline
\end{tabular}

DOI: $10.24263 / 2225-2924-2017-23-4-18$

\section{ВПЛИВ ФЕРМЕНТНИХ ПРЕПАРАТІВ НА КОЛОЇДНУ СТІЙКІСТЬ ПИВА}

\section{В.М. Кошова, Т.Г. Мисюра, Н.В. Попова \\ Національний університет харчових технологій}

У статті наведено результати дослідження впливу ферментних препаратів на колоїдну стійкість пива за умови внесення їх в різних концентраціях, на різних стадіях процесу та вдосконалення технології виробництва пива стійкого до колоїдного помутніння шляхом застосування ферментних препаратів протеолітичної діï. Встановлено значення параметрів, що забезпечують оптимальне значення показника прогнозованої стійкості готової продукиії, та фактори, що дадуть змогу прискорити технологічний цикл виробництвва, отримати готову продукиію з високими показниками колоїдної стійкості.

Ключові слова: ферменти, гідроліз, колоїдна стійкість, білки, бродіння.

Постановка проблеми. Шлях України до Всесвітньої торговельної організації (BТО) призвів до підвищення частки імпортованого пива майже вдвічі порівняно з 2008 роком, тому для економіки України важливим $€$ підвищення колоїдної стійкості цього напою. Значна частина речовин пива, які зумовлюють його характерні риси: смак, прозорість, здатність до піноутворення, ігристість тощо, перебуває у колоїдному стані $[1 ; 4 ; 5]$. 
Основними чинниками, що впливають наутворення колоїдного помутніння пива, $\epsilon$ температура, час зберігання, перемішування, дія світла, загальний вміст колоїдних речовин у пиві, вміст кисню і важких металів. Вважається, що основними речовинами, що викликають утворення колоїдного помутніння в пиві $\epsilon$ білки та поліфеноли, тому необхідно зменшити вміст однієї з цих груп речовин.

Способи, що забезпечують колоїдну стійкість пива, можна умовно поділити на три групи: хімічні, адсорбційні, ферментативні. Ми зупинились на ферментативних, тобто на застосуванні протеаз, які руйнують високомолекулярні поліпептиди $[1 ; 2 ; 5]$.

Мета статті: дослідити, яким чином ферментні препарати (ФП) впливають на колоїдну стійкість пива та безпосередньо на органолептичні показники готової продукції, визначити на яких стадіях технологічного процесу та в яких дозах введення ферментних препаратів дає максимальну стійкість пива.

Викладення основних результатів дослідження. Дослідження проводились на базі виробничої лабораторії пивзаводу. Були застосовані ферментні препарати зарубіжного виробництва, що задаються на різних стадіях процесу (Brewers Clarex, Profix 6500).

Пивне сусло в лабораторних умовах зброджувалося в мікробіологічних пляшках ємкістю 1 дм $^{3}$, попередньо простерилізованих на водяній бані. Ферментні препарати вносились мікропіпеткою, Brewers Clarex задавали на початку головного бродіння, Profix 6500 - перед пастеризацією. Як контрольний зразок зброджувалося аналогічне пивне сусло, в яке ФП не вносилися на жодній стадії технологічного процесу.

Головне бродіння для всіх дослідних зразків проводилося в термостаті при температурі $14^{\circ} \mathrm{C}$ протягом 7 діб. Доброджування та дозрівання проводилось при температурі $0^{\circ} \mathrm{C}$. Для контрольного зразка тривалість доброджування складала 7 діб, для зразків з ФП Brewers Clarex - 5 діб. Перед пастеризацією вводився ФП Profix 6500. Пиво пастеризували при $t=72^{\circ} \mathrm{C}$ протягом 3 хвилин.

Всі зразки були проаналізовані на вміст речовин, що $є$ попередниками утворення колоїдного помутніння та показників, що обумовлюють його стійкість.

Для того щоб обрати оптимальні дози ФП, в дослідні зразки вводилися рекомендовані дози (встановлені інструкцією) з рівноважним відхиленням в меншу та більшу сторону.

Перед початком головного бродіння в пивне сусло вводився ФП Brewers Clarex у концентраціях, відповідно, 0,150, 0,175 та 0,200 г/дал сусла. Після закінчення фільтрування пива у відповідні зразки окремо вводився ФП Profix 6500 в кількості 0,2 і 0,3 г/дал пива. Отримані результати наведені в табл. 1.

Таблиця 1. Показники колоїдної стійкості дослідних зразків

\begin{tabular}{|c|c|c|c|c|c|c|c|c|c|c|}
\hline \multirow{5}{*}{ Показники } & \multirow{2}{*}{$\begin{array}{c}\text { Кон- } \\
\text { троль }\end{array}$} & \multicolumn{9}{|c|}{ Концентрація Brewers Clarex, г/дал } \\
\hline & & \multicolumn{3}{|c|}{0,150} & \multicolumn{3}{|c|}{0,175} & \multicolumn{3}{|c|}{0,200} \\
\hline & Без & Без & $+0,2$ & $+0,3$ & Без & $+0,2$ & $+0,3$ & Без & $+0,2$ & $+0,3$ \\
\hline & доба- & добавок & г/дал & г/дал & добаво & г/дал & г/дал & добавок & г/дал & г/дал \\
\hline & вок & Profix & Profix & Profix & K Profix & Profix & Profix & Profix & Profix & Profix \\
\hline 1 & 2 & 3 & 4 & 5 & 6 & 7 & 8 & 9 & 10 & 11 \\
\hline $\begin{array}{c}\text { Загальнорозчи- } \\
\text { нний азот, } \\
\text { мг/100 см }\end{array}$ & 84,50 & 82,00 & 79,40 & 78,50 & 75,10 & 74,60 & 74,30 & 74,80 & 72,00 & 70,80 \\
\hline
\end{tabular}


Продовження табл. 1

\begin{tabular}{|c|c|c|c|c|c|c|c|c|c|c|}
\hline 1 & 2 & 3 & 4 & 5 & 6 & 7 & 8 & 9 & 10 & 11 \\
\hline $\begin{array}{l}\text { Коагульований } \\
\text { азот, мг } / 100 \mathrm{~cm}^{3}\end{array}$ & 1,40 & 1,38 & 1,32 & 1,28 & 1,36 & 1,35 & 1,28 & 1,29 & 1,18 & 0,93 \\
\hline $\begin{array}{c}\text { Азот осаджений } \\
\mathrm{MgSO}_{4}, \mathrm{Mr} / 100 \mathrm{~cm}^{3}\end{array}$ & 15,90 & 13,90 & 13,40 & 13,60 & 13,30 & 13,20 & 12,60 & 12,80 & 13,00 & 11,70 \\
\hline $\begin{array}{c}\text { Поліфенольні } \\
\text { речовини, мг/дм }\end{array}$ & 266,00 & 260,00 & 263,00 & 261,00 & 258,00 & 260,00 & 258,00 & 254,00 & 257,00 & 255,00 \\
\hline $\begin{array}{c}\text { Межа осадження } \\
\text { сульфатом амо- } \\
\text { нію, см}{ }^{3} / 100 \mathrm{~cm}^{3}\end{array}$ & 10,00 & 14,00 & 12,00 & 12,00 & 16,00 & 15,00 & 16,00 & 17,00 & 18,00 & 19,00 \\
\hline Мутність, ЕВС & 0,47 & 0,37 & 0,34 & 0,34 & 0,36 & 0,34 & 0,30 & 0,32 & 0,32 & 0,31 \\
\hline $\begin{array}{c}\text { Дегустаційна } \\
\text { оцінка пива, бали }\end{array}$ & \begin{tabular}{|c|}
21,6 \\
(зали- \\
шкова \\
гіркота)
\end{tabular} & $\begin{array}{c}21,6 \\
\text { (хоро- } \\
\text { ший } \\
\text { смак, } \\
\text { аромат) }\end{array}$ & $\begin{array}{c}21,6 \\
\text { (пус- } \\
\text { тува- } \\
\text { тий } \\
\text { смак) }\end{array}$ & 22,60 & 23,00 & \begin{tabular}{|c|}
23,20 \\
(хоро- \\
ший \\
смак, \\
аромат
\end{tabular} & 22,70 & $\begin{array}{c}22 \\
\text { (окисле- } \\
\text { ний } \\
\text { аромат) }\end{array}$ & 22,30 & $\begin{array}{c}21,90 \\
\text { (пус- } \\
\text { тува- } \\
\text { тий } \\
\text { смак) }\end{array}$ \\
\hline $\begin{array}{l}\text { Прогнозована } \\
\text { стійкість, місяців }\end{array}$ & 2,16 & 2,40 & 2,78 & 2,89 & 3,21 & & 3,44 & 3,22 & 3,19 & 3,08 \\
\hline
\end{tabular}

Як видно з табл. 1, із збільшенням концентрації ФП Brewers Clarex з 0,150 до 0,200 г/дал зменшується вміст азотистих речовин, які $є$ попередниками утворення колоїдного помутніння, мутність пива зменшується в допустимих межах.

На рис. 1 показаний вплив способу обробки досліджуваних зразків пива ФП на показник прогнозованої стійкості готової продукції у місяцях.

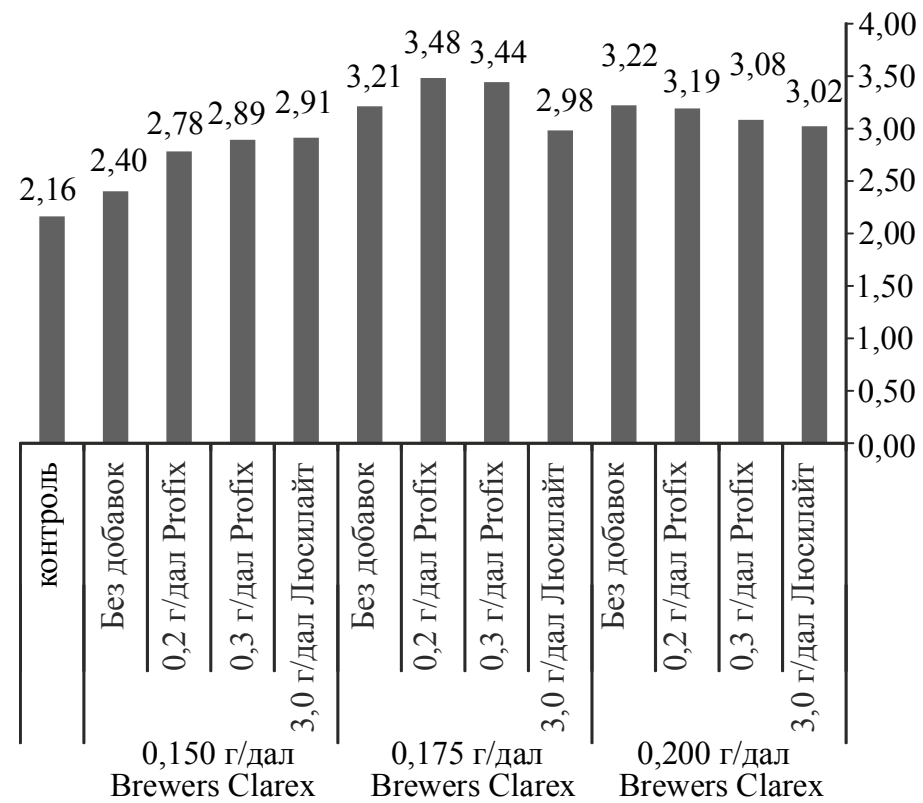

Рис. 1. Вплив способу обробки досліджуваних зразків пива ферментними препаратами на показник прогнозованої стійкості готової продукції 
3 рис. 1 можна зробити висновок, що при поєднанні ФП Brewers Clarex та Profix 6500 у кількості, відповідно, 0,175 та 0,200 г/дал досягається оптимальний результат.

Це обумовлено максимальним значенням показника для дослідного зразка № 7, яке становить 3,48 місяця, що на $38 \%$ перевищує стійкість, визначену для контрольного зразка.

На рис. 2 показана залежність вмісту коагульованого азоту в дослідних зразках пива від способу обробки ФП.

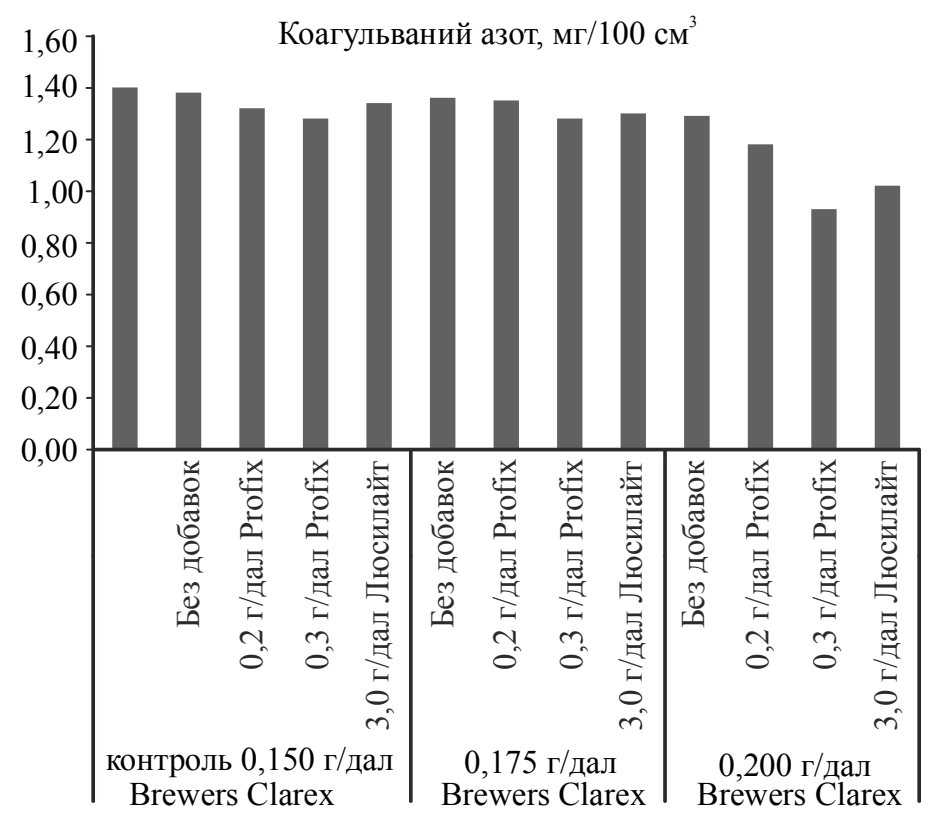

Рис. 2. Залежність вмісту коагульованого азоту в дослідних зразках пива від способу обробки ферментними препаратами

Як видно 3 рис. 2, вміст коагульованого азоту при застосуванні ФП Brewers Clarex в кількості 0,200 г/дал в поєднанні з іншими стабілізуючими засобами значно знижується, а це може призвести до погіршення піностійкості готової продукції (зразки 12 і 13). Потрібно враховувати, що нормативне значення складає 1,0-1,5 мг/100 $\mathrm{cm}^{3}$ для світлого пива [3], тому оптимальною дозою ФП Brewers Clarex є 0,175 г/дал пива.

На рис. 3 показаний вплив способу обробки досліджуваних зразків пива ФП на показник мутності. На основі показника мутності можна зробити висновок, що всі дослідні зразки знаходяться в межах оцінки «добре».

Результатом проведених досліджень $є$ рекомендації щодо застосування ФП у співвідношенні 0,175 г/дал Brewers Clarex (задавати перед зброджуванням і дозріванням) і 0,2 г/дал Profix 6500 (перед розливом). Таке дозування дасть змогу прискорити технологічний цикл виробництва, отримати готову продукцію з високими показниками колоїдної стійкості. 


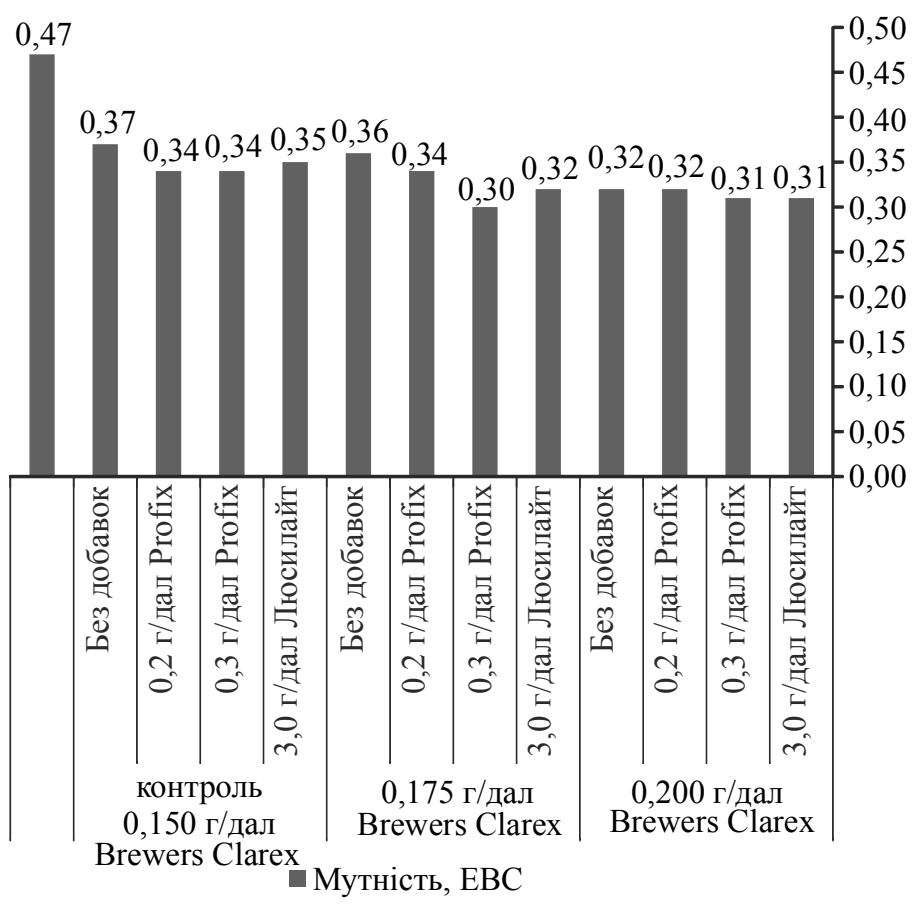

Рис. 3. Вплив способу обробки досліджуваних зразків пива ферментними препаратами на показник мутності пива

Порівняльна характеристика фізико-хімічних показників готового пива (контроль і рекомендований зразок) наведена в табл. 2, з якої видно, що коли збільшується колоїдна стійкість, зменшується загальний і коагульований азот, зменшується кількість поліфенольних речовин і антоціаногенів, які також беруть участь у колоїдному помутнінні.

Таблиия 2. Порівняльна фізико-хімічна характеристика пива

\begin{tabular}{|c|c|c|}
\hline Показники пива & $\begin{array}{l}\text { Значення показників у } \\
\text { контрольному зразку }\end{array}$ & $\begin{array}{c}\text { Значення показників у } \\
\text { дослідному зразку за умови } \\
\text { внесення 0,175 г/дал Brewers } \\
\text { Clarex та 0,2 г/дал Profix }\end{array}$ \\
\hline 1 & 2 & 3 \\
\hline $\begin{array}{c}\text { Масова частка сухої речовини в } \\
\text { початковому суслі, \% }\end{array}$ & 12,00 & 12,00 \\
\hline $\begin{array}{c}\text { Колір пива, см }{ }^{3} 0,1 \text { моль/дм }{ }^{3} \\
\text { p-ну йоду на } 100 \text { cм }^{3} \text { води }\end{array}$ & 0,69 & 0,65 \\
\hline Активна кислотність (рН) & 4,6 & 4,4 \\
\hline $\begin{array}{c}\text { Кислотність, } \text { см }^{3} 1 \text { моль/дм } \\
\text { р-ну лугу на } 100 \mathrm{~cm}^{3} \text { пива }\end{array}$ & 2,8 & 2,6 \\
\hline Кінцева ступінь зброджування, \% & 84,3 & 85,2 \\
\hline Фактична ступінь зброджування & 83,1 & 84,3 \\
\hline Різниця між КСЗ та ФСЗ, \% & 1,2 & 0,9 \\
\hline Дійсний екстракт, \% & 5,04 & 4,68 \\
\hline Видимий екстракт, \% & 2,38 & 2,17 \\
\hline
\end{tabular}




\begin{tabular}{|c|c|c|}
\hline & & Продовження табл. 2 \\
\hline 1 & 2 & 3 \\
\hline Недоброд, \% & 0,19 & 0,18 \\
\hline Загальний азот, мг/100 см ${ }^{3}$ & 84,5 & 74,6 \\
\hline Коагульований азот, мг $/ 100 \mathrm{~cm}^{3}$ & 1,4 & 1,35 \\
\hline $\begin{array}{c}\text { Азот, осаджений MgS04, } \\
\text { мг/100 см}{ }^{3}\end{array}$ & 15,9 & 13,2 \\
\hline Поліфенольні речовини, мг/дм ${ }^{3}$ & 266 & 260 \\
\hline Антоціаногени, мг/100 дм ${ }^{3}$ & 93,8 & 84,1 \\
\hline
\end{tabular}

\section{Висновки}

1. Оптимальне значення показника прогнозованої стійкості готової продукції досягається при поєднанні ФП Brewers Clarex та Profix 6500 у кількості, відповідно, 0,175 та 0,200 г/дал.

2. Застосування ферментних препаратів у співвідношенні 0,175 г/дал Brewers Clarex (задавати перед зброджуванням і дозріванням) і 0,2 г/дал Profix 6500 (перед розливом) дасть змогу прискорити технологічний цикл виробництва, отримати готову продукцію 3 високими показниками колоїдної стійкості.

3. Встановлено, що при збільшенні колоїдної стійкості зменшується загальний і коагульований азот, з кількість поліфенольних речовин і антоціаногенів.

\section{Література}

1. Купие B. Технология солода и пива. Перевод с нем. - Санкт-Петербург, Издательство «Профессия», 2003. - $912 \mathrm{c}$.

2. Ермолаева Г.А. Повышение стойкости пива / Г.А. Ермолаева // Пиво и напитки. 2003. - № 3. - С. $10-11$.

3. Царьков Д.А. Повышение стойкости пива / Д.А. Царьков, Д.В. Карпенко, Е.В. Казьмина // Пиво и напитки. - 2006. - № 5. - С. 26-27.

4. Пиво. Загальні технічні умови: ДСТУ $3888-2015$ [Чинний від 01.01.2017]. Київ : Приватне акціонерне товариство «Українська галузева компанія по виробництву пива, безалкогольних напоїв та мінеральних вод «УКРПИВО».

5. Nelson R., Ithle S., Lewis L. et. al. Trends in food science and technology // Amer. Vet. Res. - 2001. - Vol. 52, № 12. - P. 2060-2066. 